Fikrah: Jurnal Ilmu Aqidah dan Studi Keagamaan

issn 2354-6174 eissn 2476-9649

Tersedia online di: journal.iainkudus.ac.id/index.php/fikrah

Volume 8 Nomor 12020 , (1-24)

DOI: $10.21043 /$ fikrah.v8i1.7064

\title{
Mitologi dan Konstruksi Budaya Masyarakat Bubakan Mijen Semarang dalam Tinjauan Roland Barthes
}

\author{
Fakhrudin Aziz \\ Universitas Islam Negeri Walisongo, Semarang, Indonesia \\ Fakhrudin.aziz81@gmail.com
}

\begin{abstract}
Abstrak
Artikel ini mengkaji proses konstruksi makna mitologi yang berpengaruh terhadap rekonstruksi budaya di masyarakat. Penulis menggunakan teori Semiotika Roland Barthes. Melalui teori ini, mitologi dikaji berdasarkan signifikasi makna, dari denotasi ke konotasi melalui operasionalisasi tanda (sign), penanda (signifier), dan petanda (signified). Obyeknya adalah masyarakat Bubakan Mijen Semarang. Pengambilan data dilakukan dengan observasi dan wawancara. Hasilnya, varian budaya pada masyarakat Bubakan Mijen Semarang seperti punggahan, pudunan, dan kabumi berakar dari mitologi yang muncul dan diwariskan secara turun temurun (ultimate value) dari generasi ke generasi dengan dipengaruhi faktor ideologi, geografi, ekonomi, dan pendidikan. Artikel ini penting untuk mengetahui akar budaya masyarakat melalui reposisi mitologi, dari pengetahuan sederhana (historical science) menjadi pengetahuan formal-akademis (formal science).
\end{abstract}

Kata kunci: budaya, kejawen, mitos, semiology 


\begin{abstract}
This article examines the process of meaning construction of mythology which takes its toll on cultural reconstruction in a society. The researcher employed Roland Barthes's Semiotic theory. By this theory, mythology is examined based on the significance of meaning, from denotation to connotation through the operationalization of sign, signifier, and signified. The object of this research is the people of Bubakan Mijen Semarang. The data collection technique includes observation and interview. This study shows that the cultural variants in the Bubakan Mijen Semarang community such as punggahan, pudunan and kabumi are rooted in mythology which emerged and passed down from generation as an ultimate value which is influenced by the factors of ideology, geography, economics, and education. This article signifies the importance of knowing the cultural roots of society through the repositioning of mythology, from historical science to formal science.
\end{abstract}

Keywords: culture, kejawen, myth, semiology

\title{
Pendahuluan
}

Nama "Bubakan" diambil dari kata "Bubak Yoso" yang berarti kawitan (permulaan). Sebelum menjadi hunian, wilayah ini dulunya banyak ditanami pohon Jati. Bubakan berkaitan erat dengan legenda Jati Ombo (jati: kayu jati, ombo: lebar). Alkisah, ketika Sunan Kalijaga hendak membangun Masjid Demak, ia membutuhkan kayu jati untuk tiang masjid. Setelah melalui serangkaian tirakatan, Sunan Kalijaga memutuskan untuk mengambil kayu jati di daerah ini. Kayu jati dikirimkan ke Demak dengan cara dihanyutkan di Sungai Bubakan agar terbawa arus hingga sampai ke Demak. Ketika kayukayu tersebut tersangkut di wilayah Goa Kreo, Sunan Kalijaga meminta kerakera di Goa Kreo untuk mendorongnya agar terbawa arus hingga Demak. Sesampainya di Demak, kayu-kayu jati tersebut dipakai untuk tiang masjid. Mengapa disebut jati ombo? Ukurannya normal seperti kayu jati pada umumnya. Ketika dipasang sebagai tiang (soko) Masjid Demak, ukuran jati tersebut seperti jumlah jati yang tak seberapa, melebar dan kebutuhannya tercukupi. Ketika Sunan Kalijaga menebang pohon jati, ada ular naga berukuran besar dan panjang. Ular itu disinyalir sebagai penampakan sang danyang, yang datang dan pergi. Terkadang muncul dalam bentuk ular naga bersayap seperti burung, terkadang dalam wujud orangtua. Oleh masyarakat, ular ini dinamakan dengan Ontobogo. Bagi masyarakat Bubakan, Ontobogo dipercaya sebagai danyang daerah Bubakan di sekitarnya. Berbagai fenomena, seperti kecelakaan, kesurupan, gagal panen, seringkali dihubungkan dengan Ontobogo. 
Fenomena demikian dalam pemikiran masyarakat kejawen pada umumya -termasuk di Bubakan- dikenal dengan ngelmu titen; ilmu yang didasarkan pada kesamaan kejadian, pola, waktu, dan tempat. Di antara ngelmu titen tersebut adalah ketika masyarakat membuang sampah di sembarang tempat, kebut-kebutan di jalan, tidak memberikan sesajen, melakukan malima, selalu ada musibah, misalnya gagal panen, kecelakaan, dan wabah penyakit. Bagi sebagian besar masyarakat, musibah ini pertanda kemarahan Ontobogo. Inilah yang mendorong masyarakat untuk melakukan beragam selametan, seperti punggahan, pudunan, kabumi, dan sejenisnya. Tujuannya, mencegah kemarahan Ontobogo. Risdianawati mencatat, sikap ini dipengaruhi oleh situasi dan pengalaman mistis yang selalu dialami oleh masyarakat (Risdianawati \& Hanif, 2015, hal. 30-32). Kondisi ini mendorong masyarakat untuk merumuskan gagasan, ide-ide, dan nilai untuk memenuhi keinginannya.

Secara genealogis, mitos di Bubakan, tidak bisa dilepaskan dari mitos Jawa pada umumnya yang bermula dari legenda Sri (penjelmaan Dewi Laksmi) dan Sadono (penjelmaan Wisnu). Endraswara (2015) mendeskripsikan mitos itu bahwa keduanya diminta turun ke Arcapada untuk menjadi nenek moyang di Jawa. Keduanya bertemu di Gunung Tidar Magelang dan menancapkan tetenger (tanda) berupa paku di Tanah Jawa. Keturunan Sri dan Sadono semakin banyak, ada yang baik dan diasuh Semar. Sementara Togog diperintahkan mengasuh yang buruk. Mitos tentang Sri dan Sadono dijelaskan melalui falsafah Ajisaka (Aji: raja yang dihormati, saka: penyangga) yang melahirkan aksara Jawa. Ajisaka dikenal luas oleh masyarakat Jawa sebagai falsafah yang memperkokoh diri manusia. Inilah inti dari mistik kejawen yang memiliki saka guru yang berjumlah empat. Kedatangan Ajisaka ke Jawa -yang didahului dengan pertarungan melawan Dewata Cengkar, sang pemangsa manusia- menjadikan Jawa lebih beradab dan berbudaya. Kemenangan Ajisaka menjadi perlambang bahwa kebaikan akan selalu menang melawan keburukan. Marzali (2017, hal. 72) mencatat, penelusuran tersebut penting untuk memahami fenomena keagamaan.

Transformasi agama, dari agama alamiah (natural religion) menjadi agama wahyu (revealed religion). Transformasi ini bagi Tohir (2010, hal. 165) bersifat alamiah karena dalam beragama, pemeluknya membutuhkan sistem pengetahuan dan sistem keyakinan yang diekspresikan melalui simbolsimbol tertentu. Pada konteks ini, penggunaan simbol ditempatkan dalam bingkai emotik keagamaan. Deskripsi tentang sejarah mitologi di atas 
menjelaskan bahwa fenomena di Bubakan merupakan bagian dari periode panjang mitologi di Jawa. Budaya selametan seperti punggahan, pudunan, dan kabumi dilandasi oleh sikap emotik, antara menjalankan syariat Islam dan mempertahankan budaya sehingga terjadi metamorfosa dari tradisi lokal (low tradition) menjadi agama formal (high tradition) yang saling melengkapi. Budaya memberikan nilai sosial, sementara agama memberikan nilai spiritual (Roibin, 2015, hal. 33-36). Konsekuensi sosialnya, terjadi perpindahan otoritas, dari otoritas masyarakat komunal (umum) ke otoritas individual (tokoh masyarakat). Bahkan kepada pemegang otoritas kekuasaan (Mahendradhani, 2017, hal. 113).

Fokus permasalahan dalam artikel ini dapat dirumuskan menjadi dua; pertama, bagaimana masyarakat Bubakan mengkonstruksi mitologi? Kedua, bagaimana mitologi mengkonstruksi budaya di masyarakat? Untuk mengkajinya, penulis menggunakan teori semiotika Roland Barthes yang menerjemahkan mitos dengan dua prosedur; pertama, meletakkan mitologi sebagai tipe wicara (type of speech); kedua, memposisikan mitologi sebagai sistem semiologi (semiological system) dengan pola signifikasi makna denotatif ke makna konotatif melalui operasionalisasi sign, signifier, dan signified. Teori ini tepat untuk mereposisi mitologi, dari historical science menjadi formal science sehingga permasalahan penelitian dapat terjawab. Artikel ini bertujuan untuk meletakkan mitologi dan beranekaragam implikasi kulturalnya sebagai obyek kajian akademis yang terbuka untuk dikaji dan dikritisi. Mitologi sering distribusikan pada dua hal: pertama, mitologi sebagai fenomena fiktif dan terkesan mengada-ada karena berhubungan dengan fenomena tak kasat mata yang dalam diskursus keislaman disebut dengan ghaibat. Reposisi mitologi dari historical science menjadi formal science diharapkan memberikan ruang diskusi agar masyarakat tidak apriori terhadap enkulturasi budaya Jawa dengan syariat Islam yang diekspresikan beranekaragam oleh masyarakat.

Kedua, mitologi berkaitan erat dengan syirik. Asumsi ini bertolak dari pemahaman terhadap mitologi sebagai fenomena kepercayaan terhadap kekuatan ghaib yang diekspresikan melalui ragam budaya, seperti punggahan, pudunan, dan kabumi. Maka, ritualitas keagamaan yang diintegrasikan dengan budaya tersebut, dianggap sebagai sinkretisme. Inilah salah satu penyebab terjadinya polarisasi keagamaan di kalangan umat Islam. Artikel ini akan memberikan jawaban bahwa keanekaragaman budaya keagamaan yang dilahirkan di Jawa dan diwariskan secara turun temurun, adalah kekayaan 
intelektual yang harus diapresiasi. Bahkan keragaman budaya ini memberikan kekhasan dalam fenomena keagamaan di Indonesia. Dengan kata lain, Islam di Jawa tidak sama dengan Islam di Arab karena masing-masing memiliki kultur yang berbeda. Artikel ini juga akan mendeskripsikan secara komprehensif terkait eksistensi ideologi Jawa yang dapat bertahan karena dipengaruhi oleh faktor geografis, ekonomi, dan pendidikan.

\section{Semiologi Roland Barthes}

Pemikiran Roland Barthes sangat dipengaruhi oleh pemikiran Ferdinand de Saussure yang mendefinisikan antara kata langage, langue, dan parole. Secara ringkas, langue adalah bahasa baku yang diterima oleh masyarakat sebagai bahasa komunikasi yang memungkinkan adanya pemahaman di antara mereka. Sementara parole adalah bahasa sehari-hari yang dituturkan secara lugas dalam komunikasi sehari-hari. Gabungan antara keduanya disebut sebagai langage. Ferdinand de Saussure mempunyai peran dalam mencetuskan strukturalisme dan memperkenalkan semiologi. Baginya langue adalah sistem terpenting bagi manusia yang dapat dibentuk ilmu lain yang mengkaji tentang tanda-tanda dalam kehidupan sosial yang menjadi bagian dari psikologi sosial yang dinamakan semiologie (Saussure, 2006).

Roland Barthes membaca pemikiran Ferdinand de Saussure tersebut dan melihat kemungkinan adanya penerapan semiotik ke bidang lain. Jika Ferdinand de Saussure menilai linguistik sebagai bagian dari semiotik, Roland Barthes justru sebaliknya, menyebut semiotik adalah bagian dari linguistik. Terdapat struktur denotasi dan konotasi dalam semiologi Barthes. Denotasi merupakan proses signifikasi tingkat pertama (primer). Adapun konotasi adalah signifikasi tingkat kedua (sekunder) sehingga bahasa (language) bermetamorfosa menjadi metabahasa (metalanguage) yang bersifat sosial sebagai hasil dari penafsiran atas tanda-tanda yang ada. Barthes menyusun proposisi tentang mitos sebagai pesan yang disampaikan pembuat mitos itu sendiri. Mitos bukanlah gagasan, konsep, atau obyek. Mitos berhubungan dengan cara mengutarakan pesan. Secara ringkas, Barthes menjelaskan mitos melalui dua hal; pertama, mitos sebagai tipe wicara (type of speech), di mana mitos sebagai alat komunikasi untuk menyampaikan suatu pesan dengan menghadirkan sebuah pemahaman sehingga nampak sebagai hal yang ilmiah dan alamiah; kedua, mitos sebagai sistem semiologi (semiological system) yang berhubungan dengan tanda dan penanda. Mitos dikaji berdasarkan atas; sign (tanda), signifier (penanda), dan signified (petanda) (Barthes, 1972). 


\section{Mitologi; dari Historical Science ke Formal Science}

Bagi Barthes (1972), mitologi sebagai obyek formal kajian. Fokusnya pada cara masyarakat memberikan makna. Obyek kajiannya bukan tentang ide, tetapi modus signifikasi (pemberian arti). Jika disimulasikan, teori Barthes tidak menekankan pada fisik pohon besar, tetapi pada cara masyarakat memberikan makna pohon besar tersebut. Ini sebagai landasan ontologis agar mitologi dapat diterima sebagai kajian ilmiah. Setiap individu, hidup dan berinteraksi dengan semesta alam, baik yang kasat mata, seperti manusia, tumbuhan, hewan, ataupun tidak kasat mata, seperti jin, setan, roh halus. Ini menghasilkan pengalaman mistik, interpretasi, dan signifikasi. Interpretasi sebagai upaya menafsirkan makna di balik kejadian, misalnya terjatuh saat ugal-ugalan di pinggir jembatan. Adapun signifikasi merupakan proses pemaknaan (process of meaning) terjadinya sesuatu, misalnya perilaku ugal-ugalan menyebabkan jin penjaga jembatan menjadi marah dan mengakibatkan pelaku terjatuh.

Kajian mitologi berhubungan dengan ideologi dan semiologi. Jika ideologi hadir sebagai historical science, semiologi sebagai formal science. Semiologi berhubungan dengan tanda (sign), penanda (signifier), dan petanda (signified). Ketiga pola ini lalu menghasilkan dua sistem semiologi; pertama, bahasa (language); kedua, metabahasa (meta-language). Bahasa (language) berkaitan dengan penuturan awal terhadap suatu benda atau fenomena, misalnya jembatan, pohon besar, bangunan tua, dan sungai. Adapun metabahasa (metalanguage) berkaitan dengan signifikasinya, misalnya jembatan, pohon besar, bangunan tua, dan sungai adalah hunian makhluk metafisis seperti jin, setan, iblis, dan roh halus lainnya (Barthes, 1967).

Barthes (1972) menyusun beberapa karakteristik mitos sebagai berikut yaitu pertama, Tautologi, yaitu upaya pendefinisian yang tidak diperdebatkan lagi, misalnya "dari sananya sudah begitu," "itu pasti dan tidak perlu diperdebatkan," "ini ghaib." Ini karakter dasar mitos. Kedua, Identifikasi, yaitu upaya mereduksi fenomena menjadi identitas fundamental. Roh halus itu ciptaan Tuhan, maka cukup diyakini, tidak perlu dilihat. Identifikasi sebagai upaya pemaknaan melalui meta-language, tidak sekedar language. Ketiga, Privatisasi sejarah, yaitu formulasi makna yang diyakini, disepakati, dan diwariskan secara turun temurun (ultimate value).

Semiologi memberikan rumusan konsep bahwa manusia tidak hanya hidup berdampingan di antara benda-benda semesta, tetapi juga di antara 
opini-opini yang diformulasikan sebagai ideologi. Dengan kata lain, mitologi berhubungan dengan bagaimana sebuah fenomena atau kejadian dimaknai oleh pemilik kebudayaan (manusia).

Masyarakat (signifier) melihat benda atau fenomena sebagai petanda (signified) dengan menggunakan tanda-tanda yang muncul (sign). Pada level ini, masyarakat menggunakan language dan fokus mengamati obyek secara fisik (denotatif). Dari pengamatan ini, masyarakat (signifier) mengkonstruksi makna-makna baru (konotatif) berdasarkan meta-language, yaitu tanda dan makna mistik di balik petanda (signified) tersebut. Proses signifikasi dari makna denotatif ke makna konotatif melahirkan budaya emotik yang dilandasi oleh pikiran-pikiran akumulatif antara sign, signifier, dan signified.

Fenomena di atas, oleh Malinowski (1954), melahirkan realitas sosial, bahwa makna yang dipersepsikan mendorong masyarakat untuk melakukan berbagai liturgi sebagai realitas sosial yang dibangun di atas mitologi dan menjadi landasan keabsahan untuk menciptakan keteraturan sosial (social order). Dari sinilah mitologi bermetamorfosa menjadi budaya yang mendorong terjadinya konsensus. Dengan kata lain, mitologi yang semula bersifat abstrak, teraktualisasi dalam kehidupan masyarakat dan mendorong lahirnya kebudayaan.

\section{Metode}

Mitologi masyarakat memiliki pengaruh terhadap konstruksi budaya, karena berorientasi pada kajian sebuah fenomena. Oleh karena itu, riset ini masuk dalam jenis penelitian lapangan (field research). Riset dalam artikel ini dilakukan dengan pendekatan kualitatif, dengan alasan; pertama, yang dikaji adalah makna suatu tindakan atau apa yang berada di balik tindakan seseorang; kedua, di dalam menghadapi lingkungan sosial, individu memiliki strategi bertindak yang tepat bagi dirinya sendiri, sehingga memerlukan kajian yang mendalam; ketiga, karena berhubungan dengan ritual dan ideologi, maka fenomena yang dikaji tidak hanya bersifat eksternal, namun dalam diri masing-masing individu; keempat, pilihan pendekatan ini memberikan peluang untuk meneliti fenomena secara holistik menurut emic view.

Sumber data dalam artikel ini menggunakan sumber data primer dan sekunder. Data primer berupa informan di lapangan yang terdiri dari tokoh masyarakat (cultural hero) dan beberapa warga (sebagai sampel). Adapun data 
sekunder diambil dari beberapa buku dan penelitian yang berhubungan dengan topik. Informan penelitian ialah penduduk kelurahan Bubakan dengan menggunakan teknik purposive sampling, di mana informannya telah ditentukan atau dipilih berdasarkan atas tujuan tertentu yang ingin dicapai. Data dikumpulkan dengan cara observasi dan wawancara. Observasi ditujukan kepada lingkungan alam, termasuk lokasi kejadian dan lingkungan sosialnya, yaitu kelurahan Bubakan Mijen Semarang. Materi yang diobservasi meliputi; pertama, formulasi mitologi di masyarakat; kedua, mitologi dan motivasi ritualitas; ketiga, mitologi sebagai dasar motivasi dalam mengkonstruksi budaya. Selain observasi, data dikumpulkan melalui wawancara dengan model snowball sampling. Dengan model ini, wawancara dilakukan dengan memilih sejumlah informan yang memiliki kaitan dan memahami persoalan sehubungan dengan topik yang diteliti. Model wawancara ini dinilai tepat karena mengungkap sebuah fenomena dalam proses sehingga tidak dapat dipetakan dari waktu ke waktu yang lain.

Pada tahap analisis, penulis mengikuti tahapan sebagai berikut; pertama, mengumpulkan data-data yang diperoleh dari obyek penelitian; kedua, focus analysis, yaitu membahas berbagai data yang terkumpul ke dalam kode-kode tentang mitologi dan budaya; ketiga, analysis. Pada tahap ini, semua data yang telah dimasukkan ke dalam kode-kode di atas akan diuraikan dengan penjelasan tertentu. Semua uraian dan penjelasan disandingkan dengan berbagai konsep yang terkait dengan literatur tertentu. Sebelum menjadi laporan akhir, hasil analisis ini akan dikonfirmasikan kembali kepada narasumber, atau orang-orang yang memiliki keahlian di bidang kajian ini. Bentuk laporan yang digunakan sebagai model adalah laporan analisis deskriptif secara mendalam (thick description).

\section{Konstruksi Mitologi Menurut Masyarakat Bubakan}

Mitologi pada masyarakat Bubakan dipengaruhi oleh faktor ideologis dan geografis. Keduanya saling berhubungan erat. Faktor ideologis dapat dijelaskan bahwa cultural hero di Bubakan adalah masyarakat kejawen yang berpegang teguh pada mitos. Faktor ideologis ini didukung oleh kondisi geografis di mana kawasan Bubakan sebagian besar berupa hutan dan persawahan. Ketersediaan sumberdaya alam mendorong sebagian masyarakat untuk memilih profesi sebagai petani dan buruh. Pilihan profesi ini berdampak sistemik terhadap dua hal; pertama, pilihan untuk tidak menempuh pendidikan tinggi karena dianggap tidak linear dengan profesi 
dan tuntutannya; kedua, pilihan untuk tidak merantau ke luar daerah karena pertimbangan pragmatisme material bahwa ketersediaan sumberdaya alam (areal pertanian) telah mencukupkan kebutuhan masyarakat, baik primer maupun sekunder. Fenomena ini menyebabkan terbatasnya akulturasi budaya dengan dunia luar sehingga karakter kejawen semakin kuat dan mendapatkan tempat persemaian. Hal ini bisa digambarkan dalam skema gambar 1.

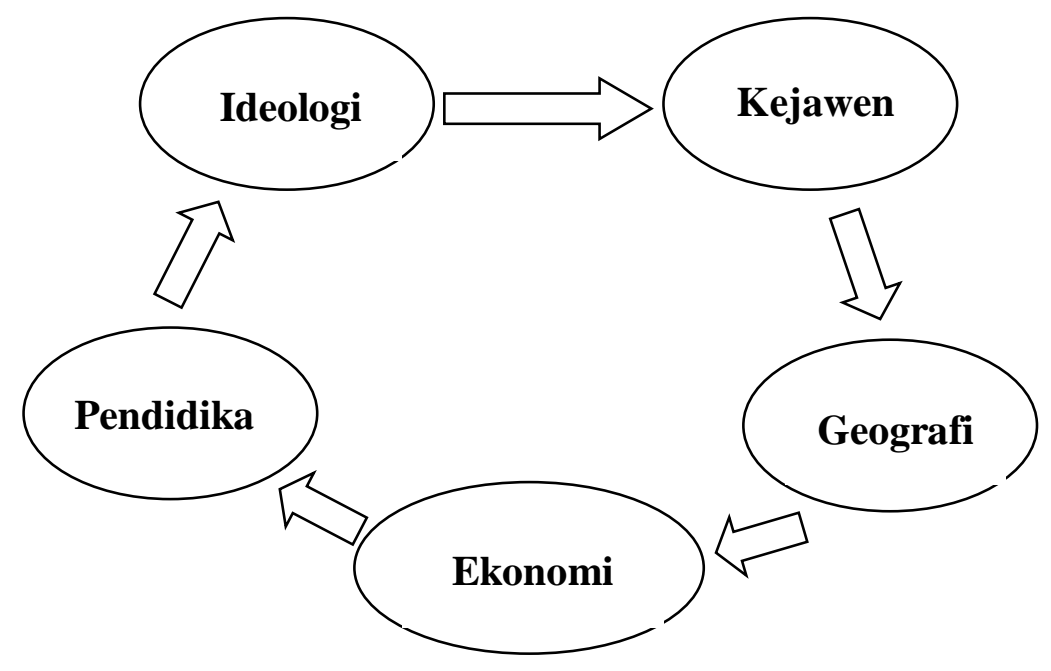

Gambar 1. Konstruksi Mitologi Masyarakat

Skema pada gambar 1 menunjukkan bahwa faktor ideologi dan faktor geografis berkontribusi besar dalam mempertahankan pola pikir masyarakat kejawen yang memegang teguh mitos. Berdasarkan teori semiologi Roland Barthes, cara masyarakat memaknai mitos dapat digambarkan pada table 1.

Tabel 1 Operasionalisasi Semiotika R. Barthes

Signifier

Masyarakat Kejawen
Signified

Kesakralan Ontobogo

$$
\text { Sign }
$$

Kecelakaan dan lainnya

Signifier

Kejawen

Sign

Malapetaka dan tindakan amoral

Budaya

Selametan

\section{Signified}

malapetaka

Skema pada tabel 1 dapat dijelaskan bahwa masyarakat kejawen (signifier) selalu mengaitkan beragam kejadian dengan eksistensi Ontobogo 
(signified). Proses signifikasi makna terjadi pada fenomena kecelakaan (sign). Ditinjau dari makna denotatif, kecelakaan terjadi akibat musibah dan atau kecerobohan (human error). Namun dari tinjauan makna konotatif, kecelakaan itu tidak lepas dari intervensi Ontobogo sebagai danyang, bahwa kecelakaan terjadi akibat kemarahan Ontobogo. Kecelakaan adalah imbas dari tindakan amoral dari pelakunya, misalnya kebut-kebutan di jalan. Fenomena ini dapat diartikan bahwa kecelakaan tersebut adalah malapetaka (signified). Ketakutan masyarakat terhadap terulangnya kejadian tersebut, mendorong mereka untuk melakukan serangkaian selametan untuk menghindari terjadinya halhal yang tidak diinginkan. Pada titik ini, budaya masyarakat mendapatkan tempat persemaian.

\section{Mitologi dan Konstruksi Budaya}

Konstruksi makna mitos melalui operasionalisasi semiologi Roland Barthes membentuk makna (the meaning) tentang eksistensi Ontobogo. Masyarakat kejawen berkepentingan menyusun nilai yang diformalisasi menjadi budaya yang disepakati masyarakat. Di antara budaya masyarakat Bubakan yang bertolak dari mitos adalah pertama, Punggahan, adalah prosesi doa bersama yang biasa dilakukan pada akhir bulan Sya'ban. Bagi masyarakat Bubakan - sebagaimana telah dikenal pada masyarakat Jawa, Sya'ban disebut sebagai Bulan Ruwah. Kata ruwah berasal dari kata arwâh, jamak dari kata rûh (roh). Masyarakat berkeyakinan bahwa pada akhir bulan Sya'ban, roh-roh nenek moyang naik ke atas. Di sinilah momentum untuk memanjatkan doa agar roh mereka tenang karena akan berdampak pada ketenangan keluarga dan masyarakat sekitar. Masyarakat berbondong-bondong mendatangi musala atau masjid untuk memanjatkan doa bersama. Jika itu tak dilakukan, muncul ketakutan bahwa roh-roh tersebut akan marah.

Kedua, Pudunan, diambil kata mudun yang berarti turun. Jika bulan Sya'ban diyakini sebagai naiknya arwah, maka pudunan -yang biasanya dilakukan di akhir Ramadhan- diyakini sebagai waktu turunnya arwah. Momentum ini oleh masyarakat Bubakan dimaknai sebagai waktu di mana para arwah kembali ke bumi. Di sinilah ragam doa perlu dipanjatkan agar para arwah diampuni dosanya sehingga arwahnya tenang.

Ketiga, Kabumi merupakan singkatan dari sedekah bumi. Masyarakat Bubakan menjadikan kabumi sebagai rutinan setiap tahun. Bahkan, pemerintah desa/kelurahan menjadikan kabumi sebagai pesta rakyat dan agenda rutin desa/kelurahan. Kabumi bagi masyarakat Bubakan adalah ikhtiar 
dengan memberikan sedekah kepada bumi dan para leluhur dengan disertai doa agar penduduk Bubakan diberikan keselamatan dan dihindarkan dari malapetaka. Masyarakat Bubakan berkeyakinan, bumi dihuni oleh makhluk ghaib. Maka kabumi tak sekedar sebagai seremonial, namun sebagai bagian dari etika relasi dengan makhluk ghaib, termasuk mendoakan untuk ketenangan para arwah leluhur. Tujuannya, agar mereka tak marah. Penyelenggaraan kabumi didasari pada keyakinan bahwa ini hak para leluhur. Kabumi biasanya identik dengan pagelaran wayang kulit semalam suntuk. Karena wayang kulit diyakini sebagai hiburan kesukaan para leluhur.

\section{Konstruksi Mitologi di Bubakan}

Kelurahan Bubakan terletak di ujung timur Kecamatan Mijen Semarang. Di sebelah utara, kelurahan Bubakan berbatasan dengan kelurahan Tambangan, kelurahan Karangmalang di sebelah timur, kelurahan Kliris di sebelah selatan, dan kelurahan Cangkiran di sebelah Barat. Secara geografis, desa ini hanya berjarak $17 \mathrm{~km}$ dari Gunung Ungaran, sehingga suhu udaranya dingin. Luasnya hutan dan sawah di Bubakan yang mencapai 257,29 Ha, berdampak pada pilihan profesi masyarakatnya, yaitu bertani, baik sebagai pemilik maupun buruh. Berdasarkan Buku Profil Kelurahan Bubakan (2019), tercatat sebanyak 794 keluarga berprofesi sebagai petani. Kondisi ini mendorong sebagian masyarakat untuk memilih profesi sebagai peternak. Ketersediaan pakan ternak yang melimpah, mendorong maraknya usaha di bidang peternakan.

Pilihan profesi mempengaruhi minat di dunia pendidikan. Bagi mereka, profesi petani tidak menuntut pendidikan tinggi. Berdasarkan catatan statistik kelurahan Bubakan, jumlah penduduk kelurahan Bubakan pada tahun 2018 sebanyak 2873 jiwa (laki-laki: 1471, perempuan: 1402). Jika jumlah Kepala Keluarga sebanyak 937, maka rata-rata rumah dihuni 3-4 jiwa dan dikategorikan keluarga kecil (nuclear family). Dari jumlah tersebut, sebanyak 237 orang tidak lulus Sekolah Dasar, 239 hanya mengenyam pendidikan hingga Sekolah Dasar (SD) dan sederajat, 246 tamat Sekolah Menengah Pertama (SMP) dan sederajat, 367 orang mengenyam pendidikan hingga Sekolah Menengah Atas (SMA) dan sederajat, dan 138 orang menyelesaikan pendidikan di perguruan tinggi. Selebihnya, belum/tidak sekolah. Ini menunjukkan rendahnya tingkat pendidikan masyarakat. Selain pendidikan formal, sebagian kecil warga memilih pendidikan informal di pondok pesantren. Selain karena biayanya murah, keterampilan dari pesantren - 
seperti yasin, tahlil, doa, dan sebagainya- dinilai cukup fungsional di masyarakat. Secara ekonomi, mayoritas masyarakat di desa ini berada pada level sejahtera kelas 2, yaitu sebanyak 294 jiwa. Biasanya mereka dari kalangan petani. Sebanyak 144 berada di level prasejahtera. Mereka berasal dari kalangan pengangguran atau tidak punya pekerjaan tetap atau sebagai buruh serabutan. Pada level kelas 1, sebanyak 98 jiwa, level 3 sebanyak 160 keluarga, level 3 plus 248 keluarga.

Ketersediaan lapangan pekerjaan di wilayah Bubakan dengan segala variasinya, menyebabkan mayoritas warga Bubakan (90 \%) memilih untuk tidak bekerja di perantauan karena pendapatan di luar kota, tidak berbeda secara signifikan jika dibandingkan dengan bekerja di Bubakan dan sekitarnya. Pertimbangan lainnya adalah ketersediaan sumberdaya alam untuk kebutuhan sehari-hari, misalnya dengan menanam sayur, palawija dan kebutuhan lainnya di sekitar rumah. Pilihan untuk tidak merantau ke luar kota, melahirkan pola interaksi yang intens antar anggota masyarakat. Mereka berangkat di pagi hari dan pulang di sore hari. Jam kantor atau pabrik biasanya antara jam 07.00 - 16.00 WIB sehingga masyarakat memiliki banyak kesempatan untuk bertemu dan bergabung dalam kegiatan kemasyarakatan.

Kondisi umum dari sisi geografis, pendidikan, ekonomi, dan sosial masyarakat Bubakan, mendeskripsikan bahwa corak kejawen memiliki ruang cukup sehingga tetap eksis. Ini dipengaruhi oleh kondisi geografis, pilihan pekerjaan, tingkat ekonomi, dan interaksi sosial di masyarakat. Ini berdampak pada pilihan masyarakat terhadap organisasi Nahdlatul Ulama (NU) sebagai salah satu organisasi yang dinilai dapat mengakomodasi budaya yang telah mengakar di masyarakat.

Identifikasi keagamaan yang tercatat dalam laporan desa, menjelaskan bahwa warga masyarakat Bubakan sebanyak 2.809 orang dicatat sebagai orang Islam, 40 orang sebagai pemeluk Kristen, dan 24 orang sebagai pemeluk Katholik. Jika ditinjau dari klasifikasi keberpihakan terhadap Ormas, seperti NU dan Muhammadiyah, komposisinya $98 \%$ mengikuti NU, dan selebihnya ke Muhammadiyah. Persentase demikian semata-mata didasarkan pada pengakuan mengenai agama yang dipeluk, dan tidak terkait dengan kualitas keagamaannya sendiri. NU sebagai mayoritas di desa ini lebih disebabkan karena kuatnya pengaruh Islam yang dibawa oleh para tokoh yang babat alas di sejumlah daerah di Jawa, yang masih melestarikan tradisi-tradisi kejawen yang diakomodasi oleh NU. 
Stratifikasi keagamaan masyarakat Bubakan, sebagaimana masyarakat Jawa pada umumnya, berupa; pertama, puritan, yaitu muslim yang secara konsisten menjalankan syariat Islam. Ini biasanya ditandai dengan keikutsertaannya dalam upacara-upacara agama; kedua, kejawen yang masih memegang teguh warisan budaya nenek moyang. Klasifikasi puritan dan kejawen tepat untuk menggambarkan kelompok masyarakat di Bubakan. Kelompok puritan diatribusikan tidak hanya kepada mereka yang mumpuni ilmu agamanya, tetapi mau menjalankan agama secara konsisten. Istilah kejawen dan abangan tidak lazim digunakan. Mereka lebih nyaman dengan istilah nasionalis. Bagi masyarakat, kejawen identik dengan klenik, sementara abangan identik dengan pelaku malima. Itulah sebabnya mereka lebih nyaman dengan sebutan nasional (is). Mereka menyebutnya wong nasional. Namun untuk kepentingan kajian, penulis menggunakan istilah kejawen agar bersesuaian dengan topik dalam artikel ini. Klasifikasi ini berbeda dengan Geertz (2013) yang membagi kelompok masyarakat Jawa menjadi tiga bagian, yaitu abangan (petani), santri (pedagang), dan priyayi (birokrat).

\section{Semiologi, Mitos, dan Konstruksi Budaya}

Berdasarkan sejarah Bubakan, Ontobogo sebagai legenda mitos adalah seekor ular raksasa yang memakai mahkota. Dalam pemahaman masyarakat kejawen, Ontobogo dipercaya sebagai penjaga wilayah Bubakan yang mampu menghubungkan energi antara manusia dan Maha Pencipta. Ontobogo tinggal di Bubakan, kepalanya di belik padusan di dekat perbatasan Tambangan, dan ekornya berada di dekat sungai Bubakan, jadi panjangnya hampir 750 meter. Ontobogo keluar pada waktu tertentu dan dalam wujud yang berubah-ubah. Ia dipercaya sebagai danyang Bubakan dan sekitarnya.

Masyarakat meyakini, Ontobogo dan makhluk sejenis mendiami lokasi-lokasi tertentu, seperti jembatan, pohon besar, sungai, hutan, dan sebagainya. Berdasarkan penuturan beberapa sumber di Bubakan, musibah yang terjadi, misalnya gagal panen, kecelakaan, kebanjiran, dan paceklik oleh masyarakat sering dikaitkan dengan sikap Ontobogo. Musibah itu terjadi sebagai dampak kemarahannya atas perilaku anggota masyarakat. Misalnya, buang sampah sembarangan, naik motor secara ugal-ugalan, melakukan malima, menebang pohon tanpa izin, dan sebagainya. Dari sini muncul narasi; "jaluko izin karo sing mbau rekso (mintalah izin kepada yang menjaga wilayah), "ati-ati mundak diwelehno (hati-hati, nanti ditegur)", "ati-ati ono sing nunggoni (hati-hati ada yang menunggu)". 
Sejarah mistik tentang asal muasal kejawen memberikan kekhasan dalam masyarakat Jawa. Ia memiliki budaya dialektis antara mitos, budaya, geografi, dan agama. Dialektika ini lalu melahirkan dua unsur dalam falsafah kejawen; kembali ke fitrah alam dan ngelmu titen. Endraswara (2015) menilai bahwa masyarakat Jawa menyukai mitos. Perilakunya selalu dikaitkan dengan hal tak kasat mata sehingga sistem berfikir mistis mendominasi perilaku masyarakat Jawa. Karena sistem inilah pola-pola hidup bersandar pada nasib hingga mencapai pemikiran homologi antropokosmik, bahwa kehidupan manusia dipengaruhi oleh tata manusia dan dunia sekelilingnya. Mistik kejawen adalah laku spiritual Jawa yang dilandasi oleh cinta dan pengalaman nyata. Dalam bahasa Glock (1965), pengalaman manusia akan mengkonstruksi perasaan, persepsi, dan sensasi sehingga menghasilkan otoritas transendental.

Mistik kejawen adalah manifestasi agama Jawa yang dipahami dan direfleksikan oleh masyarakat Jawa. Apa yang dilakukannya, berdasarkan atas ngelmu titen yang diolah dengan rasa dan dijalankan dengan laku. Esensi agama Jawa terletak pada pemujaan terhadap nenek moyang dan leluhur yang diwujudkan melalui sikap mistik dan slametan. Meskipun secara fisik yang dipuja adalah leluhur, esensi pemujaannya tetap kepada Tuhan. Jadi mistik kejawen tetap menjadikan Tuhan sebagai sentral. Mereka meyakini bahwa Tuhan adalah sumber anugerah, sedangkan roh leluhur dan kekuatan sakti tadi hanyalah perantara saja. Bahkan, masyarakat Jawa lebih menghayati ritual-ritualnya sebagai tindakan visual mistik dan memandangnya sebagai representasi harapan yang penuh pengorbanan secara ikhlas, lahir dan bathin. Bagi Nasrudin (2019), masyarakat yang berpegang teguh pada mistis tidak akan mau melepaskan ritual, karena itu dianggap sebagai bagian integral dalam agama. Di sinilah agama menyemai ruang berekspresi yang beragam.

Jika titik sentral agama adalah Tuhan, maka mistik kejawen masyarakat Bubakan telah memenuhi hal itu. Jika tujuan tersebut dicapai dengan melakukan serangkaian ritual, maka mistik kejawen mengenal laku. Jika proses laku membutuhkan kitab suci, maka mistik kejawen telah memiliki ragam karya yang berisi tentang esensi hidup dan kehidupan. Jika kepercayaan kepada Tuhan berhubungan dengan kepercayaan hal-hal ghaib, maka kepercayaan mistik kejawen terhadap leluhur dan leluwur telah merepresentasikan hal tersebut. Jika ditarik ke belakang, pengenalan awal kepada Tuhan adalah dengan memuja roh-roh nenek moyang (anceptor worship) atau leluhur (animisme) dan benda-benda yang dianggap sakti 
(dinamisme). Inilah yang dianut oleh masyarakat Jawadwipa (dahulu kala). Safitrf (2018, hal. 18) dalam penelitiannya menjelaskan kondisi manusia yang meyakini adanya kekuatan ghaib. Kekuatan itu tidak dapat dilihat, tetapi dapat dirasakan. Penganut animisme meyakini eksistensi kekuatan lain di atas kekuatan manusia. Keyakinan ini melahirkan sugesti untuk melakukan ritualitas sebagai manifestasi pengharapan kepada kekuatan roh (jawanisasi) sehingga membentuk sintesis animisme-kejawen dan menghasilkan ragam budaya. Menurut Adzfar (2012, hal. 31-34), ini menjadi fenomena yang sangat wajar. Karena sejak awal budaya Jawa bersifat sangat terbuka dengan pemahaman bahwa semua agama mengajarkan kebaikan.

Animisme dan dinamisme telah mengukir sejarah panjang, sejak kebudayaan Jawa pra-Hindu dan Budha hingga datangnya Islam di Jawa. Menurut Wiryosuparto pada masa pra-Hindu dan pra-Budha, masyarakat Jawa dikenal sederhana, yang kuat solidaritasnya dan relasinya dengan pertalian darah. Maka ruh nenek moyang dianggap sebagai pengemong (pelindung) yang dipuja, disegani, dan ditakuti. Inilah embrio agama di Jawa. Fase berikutnya adalah fase masuknya Hindu dan Budha di Indonensia. Simuh (2018) mencatat, animisme dan dinamisme di Indonesia menjadi tersistem dan terstruktur sejak masuknya pengaruh Hindu dan Budha hingga melahirkan kerajaan-kerajaan di Jawa. Melalui kekuasaan raja dan cendekiawannya yang hegemonik, kerajaan mensistematisasi animismedinamisme dan bermetamorfosa menjadi agama institusional (organized religion). Maka ketika Islam masuk, ada 2 tantangan besar yang dihadapi; pertama, kelompok petani yang telah lama menganut animisme dan dinamisme; kedua, kelompok kerajaan yang telah mensistematisasi agama Hindu dan Budha dan menyebarkannya di pelosok Jawa. Faktor ini menyebabkan Islam berkembang dari pesisiran, hingga berdirilah kerajaankerajaan Islam seperti kerajaan Demak, Pajang, Mataram, dan sebagainya. Meskipun demikian, pengaruh keraton sentris dan mistis-nya tidak bisa dihilangkan begitu saja sehingga memberikan ruang persemaian sinkretisme.

Pada perkembangannya, sinkretisme dan varian mitologi di Jawa semakin berkembang hingga akhirnya terjadi pertemuan dengan Islam. Jawadwipa yang bersifat terbuka, tak menolak kehadiran Islam dan tetap melestarikan animisme dan dinamisme yang jauh lebih dulu dipegang teguh. Pertemuan animisme dan dinamisme melahirkan polarisasi kelompok; kejawen dan puritan. Menurut Aziz (2017, hal. 83), kelompok kejawen memilih untuk bertahan dengan pola kepercayaan yang tradisional 
(unorganized religion). Salah satu alasannya, mereka menghindari pengaruh agama institusional (organized religion) yang memiliki doktrin dan dogma berisikan perintah dan larangan. Inilah yang membedakan dengan kelompok puritan yang memilih berlindung di bawah agama.

Perspektif Roland Barthes menjelaskan bahwa narasi yang dituturkan oleh pemilik kebudayaan (masyarakat), berhubungan dengan dua hal; pertama, mitos sebagai tipe wicara (type of speech). Mitos diverbalkan melalui berita, komentar, dan sejenisnya. Sungai Bubakan -misalnya- tidak mengandung mitos ketika fokusnya pada fisik sungai. Namun ketika salah satu warga bercerita, bahwa pada malam Jum'at Kliwon muncul orang tua membawa tongkat di tepi sungai, di sinilah mitos penampakan Ontobogo di sungai Bubakan mendapatkan persemaian. Pada waktu yang berbeda, muncul cerita bahwa pada malam Jum'at Kliwon ada delman tanpa awak berjalan menuju Jati Ombo. Cerita ini semakin menguatkan mitos tentang Ontobogo. Inilah yang disebut dengan ngelmu titen, proposisi dasar dalam ilmu Jawa. Kedua, mitos sebagai sistem semiologi (semiological system) melalui operasionalisasi tanda (sign), penanda (signifier), dan petanda (signified) dan menghasilkan signifikasi makna, dari makna denotatif ke makna konotatif. Ditinjau dari makna denotatif, bisa jadi memang ada orang yang sedang di tepi sungai, misalnya untuk kepentingan memancing atau buang hajat. Namun ketika itu terjadi di tepi sungai dan tepat di malam Jum'at Kliwon (sign), masyarakat (signifier) menyimpulkan bahwa itu bukan manusia, tetapi penampakan (signified). Begitu juga dengan cerita delman. Secara denotatif, delman adalah salah satu moda transportasi tradisional. Namun ketika delman berjalan di areal perkebunan, di malam Jum'at Kliwon, tanpa awak, dan melewati jalur yang tidak lazim (sign), masyarakat (signifier) menyimpulkan bahwa ada penampakan makhluk ghaib di tempat tersebut (signified).

Selain dua contoh di atas, ada fenomena lain yang bukan berupa penampakan. Misalnya kecelakaan di dekat jembatan Bubakan akibat kebutkebutan. Mitologi mendapatkan persemaian ketika kejadian itu dilihat dan diceritakan oranglain. Secara denotatif, kecelakaan bisa diakibatkan oleh kesalahan manusia (human error) atau kesalahan teknis pada kendaraan. Namun masyarakat (signifier) menafsirkan lain. Ketika kecelakaan terjadi di dekat jembatan (sign), ia menyimpulkan kemarahan danyang penjaga jembatan (signified). Jika kesimpulan dihasilkan dari kesamaan pola, waktu, tempat, dan modus, inilah yang disebut dengan ngelmu titen. 
Uraian di atas menjelaskan proses signifikasi, dari makna denotatif (the first order signification) menjadi makna konotatif (the second order signification). Hasilnya, makna konotatif menjadi the meaning dan mengkonstruksi mitologi. Konstruksi makna yang semula terbatas pada language menjadi meta-language, di mana ideologi menjadi bagian yang melekat pada fenomena tersebut. Language berhubungan dengan narasi yang memberikan kesan dan diekspresikan secara lahiriah. Pada level ini, sebuah fenomena masih memfokuskan pada aspek lahiriah. Berbeda dengan metalanguage yang sudah melewati dimensi lahiriah. Karena diyakini dan dikonstruksi melalui aspek-asepk ideologis yang tak selalu dapat diverbal secara lahiriah (Barthes, 1967).

Pengalaman masyarakat Bubakan menunjukkan bahwa mitologi dikonstruksi atas dasar opini masyarakat. Opini dibangun atas berbagai kejadian (ngelmu titen). Dengan kata lain, mitologi pada masyarakat Bubakan, merupakan metamorfosis dari language ke metalanguage. Jika language berhubungan dengan pendapat dan kesimpulan, maka meta-language menghasilkan keyakinan-keyakinan yang melampaui aspek lahiriah. Mitologi menjadi sebuah fenomena yang hanya bisa diyakini karena terjadi kesamaan pola. Pola-pola ini sekali lagi didasarkan pada pengalaman empirik di masyarakat. Misalnya, ketika ritual dan sesajen tak dilakukan, hampir pasti terjadi malapetaka. Di sini tradisi bermetamorfosa, dari low tradition menjadi high tradition. Hal ini dapat diilustrasikan pada skema gambar 3.

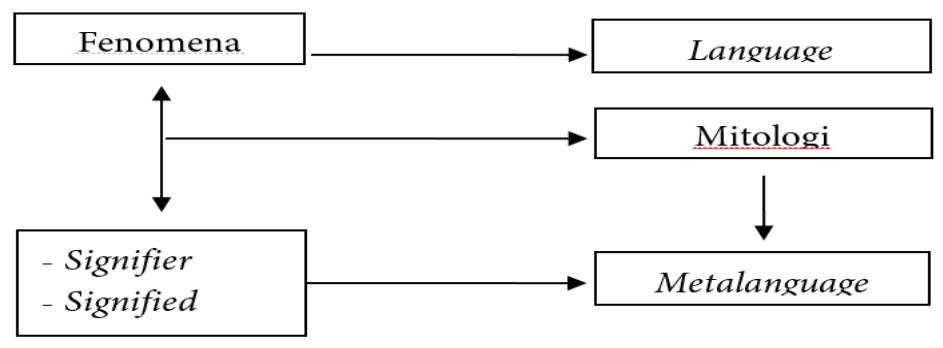

Gambar 2. Transformasi Language menjadi Meta-Language

\section{Mitologi dan Budaya Masyarakat Bubakan}

Budaya masyarakat seperti punggahan, pudunan, dan kabumi dilandasi emotik sosial-keagamaan. Metamorfosa tradisi dari tradisi sederhana (low tradition) menjadi tradisi populer (high tradition) memberikan konsekuensi bahwa kebudayaan tersebut tidak sekadar bersifat sosial, tetapi telah menjadi salah satu representasi keberagamaan. Jika merujuk definisi budaya yang ditawarkan Tylor bahwa kebudayaan adalah keseluruhan (kehidupan 
manusia) yang mencakup pengetahuan, kepercayaan, seni, hukum, moral, adat-istiadat, dan lainnya dari kemampuan dan kebiasaan yang didapatkan oleh manusia sebagai anggota masyarakat, maka ketiga budaya tersebut telah memenuhi syarat sebagai kebudayaan. Ketiga budaya di atas hanyalah sebagian dari budaya masyarakat Bubakan berakar mitologi. Bagi masyarakat Bubakan, punggahan dan pudunan memiliki kesamaan motif, yaitu membangun harmoni dengan ruh nenek moyang. Momen punggahan yang biasa dilakukan pada akhir bulan Sya'ban (Ruwah) diyakini sebagai momentum naiknya ruh. Sementara pudunan yang dilaksanakan pada akhir Bulan Ramadhan, dipercaya sebagai turunnya ruh. Dulu, ritual digelar dengan doa berbahasa Jawa berisi permohonan selamet (keselamatan), berkat (keberkahan hidup), murah rejeki (kelancaran rezeki), dan bergas waras (kesehatan). Karena kondisi awal masyarakat Bubakan adalah kejawen, yang terpenting adalah srawung (berkumpul), mangan (makan), dungo (berdoa), dan ndepe-ndepe Gusti (berharap kepada Tuhan)

Bagi masyarakat Bubakan, tradisi punggahan dan pudunan mengandung dua pesan; vertikal dan horizontal. Pesan vertikal berkaitan dengan motivasi pelaksanaannya yaitu wedi marang Gusti (takut kepada Tuhan) melalui harmoni dengan ruh nenek moyang. Pesan horizontal ditunjukkan dengan sikap ngapiki liyan (berbuat baik kepada sesama), bahwa hidup harus saling bahu membahu dalam kebaikan. Nilai solidaritas yang kuat juga terlihat dari partisipasi warga untuk membawa makanan dari rumah dan dikumpulkan jadi satu di musholla atau masjid. Masyarakat meyakini, hubungan yang harmonis, baik secara vertikal atau horizontal, mencegah amarah dari nenek moyang. Jika punggahan dan pudunan berhubungan dengan naik dan turunnya roh, kabumi berhubungan dengan sedekah kepada bumi. Masyarakat berkeyakinan, di bumi ada dayang, yang menjaga dan merawat kehidupan di bumi. Tradisi masyarakat Bubakan tersebut oleh para pendahulunya diyakini memiliki makna simbolik dan resiprokal. Dulu, hal ini dilakukan dengan menyetorkan hasil bumi sebagai bentuk terima kasih kepada Tuhan atas anugerahnya. Kabumi juga identik dengan nanggap wayang karena dianggap hiburan kegemaran pada danyang. Menurut Humaeni (2016), fenomena kultural sebagaimana di atas adalah gejala unik. Maka relijiusitas, tidak selalu harus dipahami sebagai agama (institusional) karena relijiusitas sesungguhnya berhubungan dengan kondisi kultural di masyarakat.

Berdasarkan uraian di atas, temuan dalam makalah ini menunjukkan bahwa mitologi lahir dari proses panjang Babad Tanah Jawa yang 
berhubungan erat dengan animisme dan dinamisme. Mitologi tersebut bermetamorfosa menjadi doktrin ideologi keagamaan yang dapat bertahan dan diwariskan secara turun temurun (ultimate value) dengan dipengaruhi faktor geografi, ekonomi, dan pendidikan yang terkait satu sama lain. Di sinilah mitologi mendapatkan ruang persemaian dan menjadi motivasi lahirnya enkulturasi kebudayaan masyarakat. Melalui teori Semiotika Roland Barthes, kajian komprehensif tentang mitologi mereposisi mitologi tidak hanya sebagai historical science, tetapi sebagai formal science yang terbuka untuk dikaji dan dikritisi. Inilah yang membedakan dengan kajian-kajian sebelumnya, seperti Makna Simbolik Tradisi Rebo Kasan (Rahmawati et al., 2017). Artikel ini fokus pada tradisi Rebo Kasan. Namun kajiannya belum menyentuh konstruksi mitologi dari tradisi tersebut ditinjau dari modal sosial dan ekonomi masyarakatnya. Artikel lainnya, Analisis Semiotika Roland Barthes pada Ritual Otonan di Bali (Kusuma \& Nurhayati, 2017).

Fokus artikel ini memperjelas visualisasi yang ditandai dengan gestur, pakaian, warna, dan tanda lainnya dan belum mengelaborasi proses konstruksi mitologi dari tradisi tersebut. Mirnawati (2019) menulis Analisis Semiotika dalam Teks Al-Barzanji. Fokus kajiannya terletak pada teks saja, bukan perilaku dan konstruksi sosial dari teks tersebut. Dari berbagai penelusuran, peneliti belum menemukan artikel yang secara fokus mengkaji proses terbentuknya mitos ditinjau dari sudut pandang ideologi, geografi, ekonomi, dan pendidikan serta pengaruhnya terhadap kebudayaan agama dari tinjauan semiotika Roland Barthes. Kajian tentang mitologi berjudul Mitologi Dalam Budaya Kaili di Kabupaten Sigi (Purnama) yang mengkaji mitologi dari perspektif ekologi di Kabupaten Sigi, mulai dari asal usul kerajaan Sigi hingga fungsi mitos sebagai peningkat solidaritas. Kajiannya belum mengeksplorasi faktor-faktor yang menyebabkan mitologi tetap eksis, seperti ideologi, geografi, ekonomi, dan pendidikan. Artikel berjudul Makna Simbolik dan Wujud Estetik Naga dalam Kebudayaan Jawa (Suryana, 2018) memberikan informasi yang baik tentang deskripsi Ontobogo yang sering diatribusikan sebagai simbol mitos. Artikel ini fokus pada deskripsi fisik simbol mitos, tidak pada mitos sebagai kajian kebudayaan. Pada aspek inilah tulisan pada artikel ini bisa menambah khazanah dalam diskursus mitologi.

Hasil dari kajian ini mempertegas bahwa konstruksi mitologi dan budaya masyarakat secara komprehensif menyentuh aspek geografis, ekonomi, pendidikan, dan ideologi yang saling berkaitan. Ini menjadi dasar untuk kajian mitologi secara umum agar diskursus mitologi tidak dikaji dari 
sudut pandang justifikatif dengan pendekatan normatif. Kajian ini memberikan referensi penting terhadap upaya masyarakat dalam meresepsi al-Quran dan al-Hadis melalui tradisi yang biasa dikenal dengan istilah alQuran yang hidup (living Quran) dan hadis yang hidup (living hadis) yang mengotomasi pelibatan disiplin lain, seperti sosiologi, antropologi, psikologi, dan sebagainya. Kajian serupa perlu terus dikembangkan agar kekayaan budaya masyarakat Jawa yang mayoritas berakar dari mitos dapat dikaji secara akademis. Kajian dalam artikel ini baru memotret satu wilayah saja. Kajian-kajian dengan obyek beragam dan topik sejenis sangat diharapkan agar dapat memberikan legitimasi akademis terhadap enkulturasi budaya Jawa dan Islam sebagai kekhasan Islam di Jawa.

\section{Simpulan}

Secara ideologis, mitologi masyarakat Bubakan tentang Ontobogo adalah warisan kajawen yang berprinsip pada dua hal; kembali ke fitrah alam dan ngelmu titen. Eksistensi mitologi ini dipengaruhi oleh faktor geografis, di mana ketersediaan sumberdaya alam (hutan dan sawah) menjadi pertimbangan pilihan profesi sebagai petani dan peternak, termasuk pilihan untuk bekerja di Bubakan dan sekitarnya (tidak merantau). Hal ini dengan tanpa menegasikan profesi lainnya. Tidak adanya linieritas pendidikan dengan profesi, mendorong masyarakat untuk tidak menempuh pendidikan tinggi dan merantau ke luar daerah. Fenomena ini membatasi akulturasi budaya dan menjadi penyebab bertahannya kultur kejawen di masyarakat. Ini berdampak sistemik terhadap mindset tentang fenomena Ontobogo sebagai mitos. Dari tinjauan semiotika Roland Barthes, konstruksi makna mitologi masyarakat Bubakan ditempuh melalui dua cara; mitos sebagai Tipe Wicara (type of speech) dan mitos sebagai sistem semiologi (semiological system). Di sini terjadi proses signifikansi dari makna denotatif ke makna konotatif melalui operasionalisasi sign, signifier, dan signified sehingga melahirkan budaya emotik yang dilandasi nilai mitologi.

\section{Referensi}

Adzfar, Z. (2012). Relasi Kuasa dan Alam Ghaib Islam-Jawa (Mitologi Nyai Roro Kidul dalam Naskah Wacana Sunan Gunung Jati). Lembaga Penelitian dan Pengabdian Masyarakat UIN Walisongo.

Aziz, F. (2017). Formula Pemeliharaan Agama (HifzZ Al-Din) Pada Masyarakat Desa Dermolo Jepara: Implementasi Maqāsid al-Sharī'ah dengan Pendekatan Antropologi. Al-Ahkam, 27(1), 83-110. 
https://doi.org/10.21580/ahkam.2017.27.1.1315

Barthes, R. (1967). Elements of Semiology. Jonathan Cape.

Barthes, R. (1972). Mythologies. Hill and Wang.

Bubakan, T. K. (2019). Profil Kelurahan Bubakan.

Endraswara, S. (2015). Agama Jawa; Ajaran, Amalan, dan Asal-usul Kejawen. Narasi.

Geertz, C. (2013). Agama Jawa. Komunitas Bambu.

Glock, C. Y., \& Stark, R. (1965). Religion and Society in Tension. Rand McNally.

Humaeni, A. (2016). Ritual, kepercayaan lokal dan identitas budaya masyarakat Ciomas Banten. El Harakah Jurnal Budaya Islam, 17(2), 157-181.

Kusuma, P. K. N., \& Nurhayati, I. K. (2017). Analisis Semiotika Roland Barthes Pada Ritual Otonan di Bali. Jurnal Manajemen Komunikasi, 1(2), 195-217.

Mahendradhani, G. A. A. R. (2017). Animisme dan Magis EB Tylor dan JG Frazer (Sebuah Analisis Wacana Agama). Vidya Samitha: Jurnal Penelitian Agama, 3(2).

Malinowski, B. (1954). Magic, Science, and Religion. Doubleday Anchor Book.

Marzali, A. (2017). Agama dan Kebudayaan. Umbara: Indonesian Journal of Anthropology, 1(1). https://doi.org/10.24198/umbara.v1i1.9604

Mirnawati, M. (2019). Analisis Semiotika dalam Teks Al-Barzanji. A Jamiy: Jurnal Bahasa dan Sastra Arab, 8(1), 31-52.

Nasrudin, J. (2019). Relasi Agama, Magi, Sains dengan Sistem Pengobatan Tradisional-Modern pada Masyarakat Pedesaan. Hanifiya: Jurnal Studi AgamaAgama, 2(1), 42-58.

Rahmawati, R., Nurhadi, Z. F., \& Suseno. (2017). The Symbolic Meaning of Tradition Rebo Kasan. Jurnal Penelitian Komunikasi, 20(1).

Risdianawati, L. F., \& Hanif, M. (2015). Sikap Masyarakat Terhadap Pelaksanaan Upacara Kelahiran Adat Jawa Tahun 2009-2014 (Studi Di Desa Bringin Kecamatan Kauman Kabupaten Ponorogo). Agastya: Jurnal Sejarah dan Pembelajarannya, 5(01), 30-66.

Roibin, R. (2015). Dialektika Agama Dan Budaya Dalam Tradisi Selamatan Pernikahan Adat Jawa Di Ngajum, Malang. El-Harakah, 15(1), 34-47.

Safitrf, I. (2018). Kepercayaan Gaib dan Kejawen: Studi Kasus pada Masyarakat Pesisir Kabupaten Rembang. Sabda: Jurnal Kajian Kebudayaan, 8(1), 18-28.

Saussure. (2006). Writing in General Linguistics. Duckworth.

Simuh. (2018). Sufisme Jawa; Transformasi Tasawuf Islam ke Mistik Jawa. Narasi.

Suryana, C. (2018). Makna Simbolik dan Wujud Estetik Naga dalam Kebudayaan Jawa. ARTic, 2, 83-91. https://doi.org/10.34010/artic.2018.2.2526.83-91

Thohir, M. (2010). Fundamentalisme Keagamaan dalam Perspektif Kebudayaan. Analisa: Journal of Social Science and Religion, 17(2), 1652-174. https://doi.org/10.18784/analisa.v17i2.35 
Halaman ini sengaja untuk dikosongkan 